\title{
ASSESSMENT OF PARAOXONASE-1 ACTIVITY IN DIABETES MELLITUS
}

\author{
Ramadevi Mathivanan', Sasivathanam Natarajan², Senthilkumari Subramaniyam³ \\ ${ }^{1}$ Assistant Professor, Department of Biochemistry, Thanjavur Medical College, Thanjavur, Tamilnadu. \\ 2 Professor, Department of Biochemistry, Thanjavur Medical College, Thanjavur, Tamilnadu. \\ ${ }_{3}^{3}$ Assistant Professor, Department of Biochemistry, Mohan Kumaramangalam Government Medical College, Salem, Tamilnadu.
}

\begin{tabular}{l}
\hline ABSTRACT \\
BACKGROUND \\
Diabetes mellitus is a metabolic disorder, where the risk of premature atherosclerosis causing death is considerable. Paraoxonase-1 \\
(PON-1) is an anti-atherogenic and antioxidant enzyme associated with HDL, which prevents LDL oxidation by hydrolysing lipid \\
hydroperoxides. \\
The aim of this study is to determine the serum PON-1 activity, in Diabetes mellitus patients to predict the atherogenic risk.
\end{tabular}

\section{MATERIALS AND METHODS}

Hundred subjects were chosen for the study, of which 50 healthy individuals were taken as control group and 50 diabetic (type 1 and type 2) patients as study group. PON-1 activity was measured using paraoxon as a substrate and lipid profile by enzymatic assay methods. Blood sugar was estimated by enzymatic method and HbA1c by immunoturbidimetric assay.

\begin{abstract}
RESULTS
Serum PON-1 activity $(\mathrm{p}<0.0001)$ and HDL $(\mathrm{p}<0.0001)$ were significantly decreased in study group when compared with control group. Serum Total Cholesterol, TGL, LDL, VLDL, FBS, PPBS and HbA1C were significantly increased in study group than that in the control group indicating dyslipidaemia and uncontrolled hyperglycaemia in the diabetic group. By using Pearson's correlation, PON1 activity was found to be positively correlated with HDL $(\mathrm{p}<0.01)$ and negatively correlated with age $(\mathrm{p}<0.01)$ and shows no correlation with other parameters.
\end{abstract}

\section{CONCLUSION}

In diabetes mellitus patients, there is a significant decrease in PON-1 activity and this could be an important factor in causation of premature atherosclerosis.

\section{KEYWORDS}

Paraoxonase-1, Diabetes Mellitus, Atherosclerosis, HDL, LDL, Oxidation.

HOW TO CITE THIS ARTICLE: Mathivanan R, Natarajan S, Subramaniyam S. Assessment of paraoxonase-1 activity in diabetes mellitus. J. Evolution Med. Dent. Sci. 2016;5(86):6420-6424, DOI: 10.14260/jemds/2016/1452

\section{BACKGROUND}

Diabetes mellitus is a chronic disorder that occurs when the pancreas does not produce enough insulin or when the body cannot effectively use the insulin it produces.(1) Based on latest report from the International Diabetes Federation, it is estimated that there are currently 382 million people living with Diabetes globally and this number is set to rise to 592 million by the year 2035.(2) In patients with diabetes mellitus, atherosclerotic macrovascular disease is the leading cause of morbidity and mortality and dyslipidaemia is a significant risk factor in causation of atherosclerosis. Diabetic dyslipidaemia constitutes increased triglycerides, increased VLDL, decreased HDL and mild elevation in LDL cholesterol level. In addition to quantitative alterations, qualitative abnormalities like small dense LDL and small dense HDL also exists, which is more atherogenic. There is an increased activity of cholesterol ester transfer protein, which exchanges triglycerides from VLDL for

Financial or Other, Competing Interest: None.

Submission 21-09-2016, Peer Review 14-10-2016,

Acceptance 21-10-2016, Published 27-10-2016.

Corresponding Author:

Dr. Ramadevi Mathivanan,

111, Saraboji Nagar,

Medical College Road,

Thanjavur, Tamilnadu.

E-mail: mathivanan.ramadevi@gmail.com

DOI: $10.14260 /$ jemds/2016/1452 cholesteryl esters from HDL and LDL leading to decreased HDL concentration, as TGL rich HDL is highly susceptible to catabolism by hepatic lipase. As Hepatic lipase activity is increased in DM it hydrolyses the TGL, on TGL rich LDL to produce small dense LDL, which shows greater susceptibility to oxidation and increased cardiovascular risk. Hydrolysis of TGL in HDL results in small dense HDL, which are less cardioprotective. Cholesterol esters transferred to TGL rich VLDL, render these remnant particles more resistant to lipolytic breakdown and as a result more atherogenic.(3)

Glycation confers increased susceptibility of LDL to oxidative modification and enhances its uptake by human aortic intimal cells and monocyte derived macrophages, stimulating the formation of foam cells.

Product of combined glycation and oxidation of LDL (glycoxidation) is more atherogenic than glycated or oxidised LDL alone. DM upregulates the expression of class B macrophage scavenger receptor CD36 and thereby increases OxLDL endocytosis.(4)

Oxidised LDL has several proatherogenic properties including the rapid uptake by macrophages to form foam cells, chemoattraction for circulating monocytes, promotion of the differentiation of circulating monocytes into tissue macrophages and inhibition of the mobility of resident macrophages. It is also cytotoxic to several types of cells and immunogenic. Thus, oxidation of LDL plays a major role in development of atherosclerosis in DM. 
LDL can be protected from oxidation by antioxidants that can act directly on the LDL and indirectly on the cellular oxidative machinery and by HDL associated enzyme, Paraoxonase which converts OxLDL to a non-atherogenic particle. The ability of HDL to inhibit oxidation of LDL and promote macrophage cholesterol efflux is through the action of several of its proteins, particularly Paraoxonase-1.(5)

Paraoxonase (PON)-1 is an aryl dialkyl phosphatase (E.C 3.1.8.1) synthesised mainly by the liver.(6) Association of PON1 with HDL is necessary for maintaining its normal serum activity. HDL ensures the amphipathic environment, which protects the $\mathrm{N}$-terminal hydrophobic region of this enzyme and this environment is necessary for interaction of PON-1 with substrate. Thus, the conformation of enzyme within the hydrophobic environment of HDL is crucial for its activity. (7) HDL is bound on the cell membrane via scavenger receptor $B_{1}$ (SRB1). PON-1 which was inserted into the external surface of the cell membrane is then transferred on HDL during transient association of the lipoprotein with the cell.(8) HDL protects LDL against lipid peroxidation by acting as a reservoir for lipid peroxides generated on LDL and the phospholipid hydroperoxides are hydrolysed by the PON-1. HDL then transfers the oxidised cholesteryl esters to the liver for disposal.(9) Thus, the protective effect of HDL may not be dependent on the absolute levels of HDL cholesterol in the blood, but rather the abundance of HDL particles which contains the protective enzymes PON-1.(10) The present study is done to assess the activity of PON-1 in diabetic individuals, thereby to predict the atherogenic risk.

\section{MATERIALS AND METHODS}

The study was conducted at Thanjavur Medical College, Thanjavur, after getting the approval from the Ethical Committee of Thanjavur Medical College, Thanjavur. Hundred subjects were chosen for the study. Both males and females in the age group of 21-72 years were included and an informed consent was obtained from all of them. Control group consists of 50 healthy individuals ( 25 females and 25 males) and study group consists of 50 patients with diabetes mellitus (25 females and 25 males). In the study group, both type I and type II diabetes mellitus patients with duration of diabetes from 1 to 15 years were included; 17 patients are under insulin and 33 are under oral hypoglycaemic drugs. Study group were selected from the Outpatient Department of Diabetology, Thanjavur Medical College, Thanjavur.

Patients with Liver diseases, Renal failure, Acute and Chronic infections, Thyroid disorders, Hypertension, Chronic inflammatory disorders, Smoking, Alcoholism and Patients on lipid lowering drugs and antioxidants were excluded from the study.
Blood samples were collected after overnight fast from both cases and controls. Fasting blood samples were analysed for paraoxonase-1 activity, fasting blood glucose, HbA1c and lipid profile (Total cholesterol, Triglycerides, HDL, VLDL); 2 $\mathrm{mL}$ of post-prandial venous blood sample was collected for the estimation of post-prandial blood glucose level.

Serum PON-1 activity was estimated using the paraoxon (0, 0 diethyl-0-4 nitrophenyl phosphate) as the substrate for hydrolysis. The chemicals used were of analytical reagent grade from Sigma chemicals. Serum Paraoxonase- 1 hydrolyses paraoxon in the presence of calcium at $\mathrm{pH} 8.0$ at $25^{\circ} \mathrm{C}$ and releases para-nitrophenol (P-NP). The liberated P-NP is measured and the activity of PON-1 calculated using the molar absorption of P-NP in a kinetic assay. The absorbance was measured at $405 \mathrm{~nm}$.

Serum Glucose, Total cholesterol and HDL cholesterol were estimated in fully automated analyser (Beckmann Coulter AU-480) using respective kits. Serum LDL cholesterol level was calculated from the estimated parameters using Friedewald's formula and VLDL from the formula TGL/5.

\section{STATISTICAL ANALYSIS}

The results were expressed as mean \pm standard deviation. Statistical analysis was performed using statistical package for Social Sciences. Student t-test was used to analyse difference between the two groups. Pearson's correlation was applied to correlate between the parameters. $\mathrm{P}$ value $<0.05$ was considered to be statistically significant.

\section{RESULTS}

Table I shows the serum PON-1 activity between the control $(270.50 \pm 81.11)$ and study groups $(99.19 \pm 38.71)$. There is a highly significant difference between the two groups. $(p=<0.0001)$. Table II shows the age matched comparison of serum PON-1 activity in the study and control groups and there is highly significant difference between the two groups $(\mathrm{p}=<0.0001)$. Table III shows the analysis of the values of all the parameters and it shows highly significant difference between the study and control group in all the parameters $(p=<0.0001)$. Table VI shows Pearson's correlation analysis between PON-1 activity and other variables in the study group. It shows highly significant negative correlation $(\mathrm{p}=<0.01)$ with age and highly significant positive correlation $(\mathrm{p}=<0.01)$ with HDL. Correlation with other parameters are not statistically significant $(\mathrm{p}=>0.05)$.

***Extremely statistically significant.

\begin{tabular}{|c|c|c|c|c|}
\hline Sl. No. & PON Activity (IU/L) & Mean & S.D & Statistical Inference \\
\hline 1 & Control (n=50) & 270.5084 & 81.11600 & \multirow{2}{*}{$\mathrm{P}=0.0001<0.05$ Significant } \\
\hline 2 & Study (n=50) & 99.1958 & 38.71695 & \\
\hline \multicolumn{4}{|c|}{ Table I. Comparison of PON-Activity between Control and Study Group } \\
\hline
\end{tabular}




\begin{tabular}{|c|c|c|c|c|}
\hline Age & PON Activity (IU/L) & Mean & S.D & Statistical Inference \\
\hline \multirow{2}{*}{$\begin{array}{l}21-30 \\
\text { Years }\end{array}$} & Control $(n=5)$ & 255.4440 & 91.41406 & \multirow{2}{*}{$\begin{array}{c}\mathrm{P}=.014 \\
<0.05 \\
\text { Significant }\end{array}$} \\
\hline & Study $(n=7)$ & 139.8757 & 42.48033 & \\
\hline \multirow{2}{*}{$\begin{array}{l}31-40 \\
\text { Years }\end{array}$} & Control $(n=12)$ & 268.9917 & 96.70848 & \multirow{2}{*}{$\begin{array}{c}\mathrm{P}=.0001 \\
\quad<0.05 \\
\text { Significant }\end{array}$} \\
\hline & Study $(n=10)$ & 99.3410 & 38.23719 & \\
\hline \multirow{2}{*}{$\begin{array}{l}41-50 \\
\text { Years }\end{array}$} & Control $(n=15)$ & 284.7825 & 73.27152 & \multirow{2}{*}{$\begin{array}{c}\mathrm{P}=.0001 \\
\quad<0.05 \\
\text { Significant }\end{array}$} \\
\hline & Study $(n=12)$ & 98.3258 & 35.56410 & \\
\hline \multirow{2}{*}{$\begin{array}{l}51-60 \\
\text { Years }\end{array}$} & Control $(n=10)$ & 306.5100 & 74.00833 & \multirow{2}{*}{$\begin{aligned} & \mathrm{P}=.0001 \\
&<0.05 \\
& \text { Significant }\end{aligned}$} \\
\hline & Study $(\mathrm{n}=11)$ & 91.8590 & 22.75343 & \\
\hline \multirow{2}{*}{$\begin{array}{c}>61 \\
\text { Years }\end{array}$} & Control $(n=8)$ & 245.1293 & 71.94690 & \multirow{2}{*}{$\begin{array}{c}\mathrm{P}=.0001 \\
\quad<0.05 \\
\text { Significant }\end{array}$} \\
\hline & Study $(n=10)$ & 80.7955 & 40.16491 & \\
\hline \multicolumn{5}{|c|}{ Table II. Age Matched Serum PON-1 Activity in the Study and Control Group } \\
\hline
\end{tabular}

\begin{tabular}{|c|c|c|c|c|}
\hline Sl. No. & Factors & Mean & S.D & Statistical Inference \\
\hline \multirow[t]{3}{*}{1} & PONACT (IU/L) & & & \\
\hline & Control $(n=50)$ & 270.5084 & 81.11600 & \multirow{2}{*}{$\begin{array}{c}P=0.0001 \\
<0.05 \text { Significant }\end{array}$} \\
\hline & Study $(n=50)$ & 99.1958 & 38.71695 & \\
\hline \multirow[t]{3}{*}{2} & FBS & & & \\
\hline & Control (n=50) & 80.6200 & 10.81173 & \multirow{2}{*}{$\begin{array}{c}\mathrm{P}=0.0001 \\
<0.05 \text { Significant }\end{array}$} \\
\hline & Study $(n=50)$ & 158.4000 & 50.96257 & \\
\hline \multirow[t]{3}{*}{3} & PPBS & & & \\
\hline & Control $(n=50)$ & 121.8400 & 10.78048 & \multirow{2}{*}{$\begin{array}{c}\mathrm{P}=0.0001 \\
<0.05 \text { Significant }\end{array}$} \\
\hline & Study $(\mathrm{n}=50)$ & 262.9800 & 72.50067 & \\
\hline \multirow[t]{3}{*}{4} & HbA1c\% & & & \\
\hline & Control $(n=50)$ & 4.6120 & .52085 & \multirow{2}{*}{$\begin{array}{c}\mathrm{P}=0.0001 \\
<0.05 \text { Significant }\end{array}$} \\
\hline & Study $(n=50)$ & 7.2980 & 1.07864 & \\
\hline \multirow[t]{3}{*}{5} & CHOL & & & \\
\hline & Control $(n=50)$ & 149.6600 & 8.00411 & \multirow{2}{*}{$\begin{array}{c}\mathrm{P}=0.0001 \\
<0.05 \text { Significant }\end{array}$} \\
\hline & Study $(n=50)$ & 205.9400 & 26.11936 & \\
\hline \multirow[t]{3}{*}{6} & TGL & & & \\
\hline & Control $(n=50)$ & 109.94 & 15.676 & \multirow{2}{*}{$\begin{array}{c}P=0.0001 \\
<0.05 \text { Significant }\end{array}$} \\
\hline & Study $(n=50)$ & 189.88 & 21.167 & \\
\hline \multirow[t]{3}{*}{7} & HDL & & & \\
\hline & Control $(n=50)$ & 44.2400 & 2.12430 & \multirow{2}{*}{$\begin{array}{c}P=0.0001 \\
<0.05 \text { Significant }\end{array}$} \\
\hline & Study $(n=50)$ & 35.2800 & 3.86000 & \\
\hline \multirow[t]{3}{*}{8} & LDL & & & \multirow{3}{*}{$\begin{array}{c}P=0.0001 \\
<0.05 \text { Significant }\end{array}$} \\
\hline & Control $(n=50)$ & 83.4320 & 8.86924 & \\
\hline & Study $(n=50)$ & 132.6840 & 24.74415 & \\
\hline \multirow[t]{3}{*}{9} & VLDL & & & \multirow{3}{*}{$\begin{array}{c}P=0.0001 \\
<0.05 \text { Significant }\end{array}$} \\
\hline & Control $(\mathrm{n}=50)$ & 21.9880 & 3.13516 & \\
\hline & Study $(n=50)$ & 37.9760 & 4.23333 & \\
\hline
\end{tabular}

\begin{tabular}{|c|c|c|}
\hline PON Activity (IU/L) & Correlation Value & Statistical Inference \\
\hline AGE & $-.401\left(^{* *}\right)$ & $\mathrm{P}<0.01$ Significant \\
\hline FBS & .024 & $\mathrm{P}>0.05$ Not Significant \\
\hline PPBS & .219 & $\mathrm{P}>0.05$ Not Significant \\
\hline HbA1c\% & .180 & $\mathrm{P}>0.05$ Not Significant \\
\hline CHOL & -.302 & $\mathrm{P}>0.05$ Not Significant \\
\hline TGL & .153 & $\mathrm{P}>0.05$ Not Significant \\
\hline HDL & $.551\left(^{* *}\right)$ & $\mathrm{P}<0.01$ Significant \\
\hline LDL & .207 & $\mathrm{P}>0.05$ Not Significant \\
\hline VLDL Table IV. Pearson Correlation Analysis of PON Activity with Other Variables \\
\hline \multicolumn{2}{|c}{} \\
\hline
\end{tabular}




\section{DISCUSSION}

Dyslipidaemia in Diabetes Mellitus constitutes an important determinant of atherosclerosis.(3) HDL is one of the important, independent protective factor for atherosclerosis. Paraoxonase-1 (PON-1) is an enzyme that confers the antiatherogenic and antioxidant properties to HDL, which diminishes the LDL oxidation and prevents the proinflammatory response elicited by oxidised LDL, by hydrolysing the lipid peroxides.(11) Moreover PON-1 is critical for preventing the oxidation of HDL, allowing it to maintain its function. Thus, PON-1 activity is responsible for the antiatherogenic property of HDL.(12)

The present study done with 100 subjects (50 were diabetes mellitus patients and 50 were healthy subjects) supports the fact that the measurement of PON-1 activity is useful in predicting the risk of cardiovascular disease in Diabetic patients.

Comparison of mean value of the serum PON-1 activity in the study group $(99.19 \pm 38.17 \mathrm{U} / \mathrm{L})$ with that of the control group (270.50 \pm 81.11$)$ showed a significant fall in the study group. As that of previous studies, this study also supports the fact that there is a significant decrease in PON-1 activity in Diabetes Mellitus. $(7,13,14,15,16,17)$ The mean values of serum PON1 activity between the control and the study groups in different age groups were compared and all of them showed a significant decrease in PON-1 activity in study group. Analysis of parameters of lipid profile shows that the mean values of HDL in study group is significantly decreased than that of control group. Comparison of other parameters of lipid profile showed a significant increase in the study group when compared to the control group. These differences indicate the dyslipidaemic changes in the diabetes mellitus.(18)

Among the other parameters measured fasting blood sugar, post-prandial blood sugar and HbA1C levels are significantly increased in the study group indicating the presence of uncontrolled hyperglycaemia in the study group.

In the Pearson's correlation analysis, the PON activity shows highly significant negative correlation with age in year. It shows that PON activity diminishes with the duration of DM and it could be a non-negligible factor of increased atherosclerosis development in elderly people with DM.(19) The levels of HDL shows a significant positive correlation with the PON activity. This correlation proves the association of PON with HDL.(13)

In both insulin and non-insulin dependent Diabetes Mellitus, Paraoxonase-1 activity is low which is more profound than the decrease in concentration of the enzyme.(13) Large proportion of PON protein could be inactive in DM either because of endogenous circulating inhibitors such as lipid peroxidation products or because of increased glycosylation of Paraoxonase.(14,20)

PON is anchored to the HDL lipids by its hydrophobic Nterminal end and also to be bound to $\mathrm{APOA}_{1}$. Diabetic HDL is compositionally abnormal and is possible that this affects the binding of PON to HDL leading to conformational change in PON or to availability of substrate within the hydrophobic region of HDL in which Paraoxonase is active.(13)

According to Michael I. Mackness et al, Serum PON-1 activity is likely to depend on the number of PON-1 molecules in HDL rather than the serum HDL concentration.(20) Population with DM have marked reduction in serum PON activity and it does not correlate with serum concentration of most lipids and lipoproteins.(13)
This reduction in PON activity might play a central role in causing atherosclerosis in DM, because HDL-PON activity modulates susceptibility of HDL to atherogenic modification such as glycation and homocysteinylation. The inactivation of PON-1 reduces the ability of HDL to inhibit LDL modifications and monocyte endothelial interaction. Since both these mechanisms are important in the inflammatory response of arterial wall cells, atherogenesis is favoured.(21)

PON is involved in hydrolysis of homocysteine thiolactone into homocysteine (Thiolactonase activity). Thus, decrease in PON activity may initiate a positive feedback mechanism causing further accumulation of homocysteine thiolactone, which can damage protein by homocysteinylation of the lysine residues, which are auto-immunogenic and prothrombotic leading to atherosclerosis. PON involvement in the pathogenesis of atherosclerosis is suggested by the increasing PON-1 immunoreactivity in the arterial wall as the atheroma advances. Thus, PON-1 confers protection against coronary artery disease by inactivating and removing the proinflammatory lipid oxidation products from the carotid and coronary plaque.(22)

By measuring the PON-1 activity in DM patients, we can predict the atherosclerosis earlier and it may help for taking early preventive measures against cardiovascular disease.

\section{CONCLUSION}

This study shows that there is a significant decrease in PON-1 activity in DM patients. Since PON-1 is an antiatherogenic and antioxidant enzyme associated with HDL, reduction in PON-1 activity in diabetes mellitus may play an important role in causation of premature atherosclerosis.

Based on the results obtained, the present study shows that PON-1 activity may act as a useful marker for early prediction of atherosclerosis in DM. By predicting earlier, early interventional measures by pharmaceutical means or by dietary means can be done. $(23,24)$

\section{REFERENCES}

1. Maitra A. The endocrine system. In: Vinaykumar, Abul K. eds. Robbins and Cotran pathologic basis of disease. $8^{\text {th }}$ edn. Saunders 2010. P. 1130.

2. Ramachandran A. Epidemiology of diabetes in India. Type 2 Diabetes in south east Asians-Epidemiology. In: Mohan $\mathrm{V}$, Rao GHR. Risk factors and prevention. Jaypee Brothers 2007:20-21.

3. Jameson L. Lipoprotein metabolism and the treatment of lipid disorders. In: Jameson L, Degroot L. Endocrinologyadult and paediatric. Saunders Elsveir 2010. P. 793.

4. Aronson DD, Rayfield EJ. Diabetes. In: Topal EJ, Califf RM, Prystowsky EN, et al. Text book of comprehensive cardio vascular medicine. $3^{\text {rd }}$ edn. Philadelphia, PA: Lippincott Williamsand Wilkins 2007:189-91.

5. Saxena T, Agarwal BK, Kare P. Serum paraoxonase activity and oxidative stress in acute myocardial infarction patients. Biomedical Research 2011;22(2):217-21.

6. Nabatchian F, Khaghani Sh, Miri R, et al. Apolipoprotein E polymorphism, Paraoxonase- 1 acitivity and coronary artery disease: is there a link. Pakistan Journal of medical Sciences 2008;24(2):204-8.

7. Ferritti G, Bacchetti T, Busni D, et al. Protective effect of paraoxonase activity in high-density lipoproteins against erythrocyte membranes peroxidation: a comparison 
between healthy subjects and type I diabetic patients. J Clin Endocrinol Metab 2004;89(6):2957-62.

8. Deakin S, Moren X, James RW, et al. HDL oxidation compromises its influence on paraoxonase-1 secretion and its capacity to modulate enzyme activity. Arterioscler Thromb Vasc Biol 2007;27(5):1146-52.

9. Mackness MI, Mackness B. HDL: are there any benefits in rising it in lipids and vascular disease. Current issues by Betteridge DJ. Martin Dunetz Ltd, 2002:15-17.

10. Watson AD, Berliner JA, Hama SY, et al. Protective effect of high density lipoprotein associated paraoxonase. Inhibition of the biological activity of minimally oxidized low density lipoprotein. J Clin Invest 1995;96(6):2882-91.

11. Cao H, Girard-Globa A, Berthezene F, et al. Paraoxonase protection of LDL against peroxidation independent of its esterase activity towards paraoxon and is unaffected by the Q->R genetic polymorphism. J Lipid Res 1999;40(1): 133-9.

12. Aviram M, Rosenblat M, Bisgaier CL, et al. Paraoxonase inhibits HDL oxidation and preserves its functions. A possible peroxidative role for paraoxonase. J Clin Invest 1998;101(8):1581-90.

13. Abbott CA, Mackness ML, Kumar S, et al. Serum paraoxonase activity, concentration and phenotype distribution in diabetes mellitus and its relationship to serum lipids and lipoproteins. Arterioscler Thromb Vasc Biol 1995;15(11):1812-8.

14. Altuner D, Suzen SH, Ates I, et al. Are PON1 Q/R 192 and M/L 55 polymorphisms risk factors for diabetes complications in Turkish population? Clinical Biochemistry 2011;44(5-6):372-6.

15. Connelly PW, Zinman B, Maguire GF, et al. Association of the novel cardiovascular risk factors paraoxonase 1 and cystatin $\mathrm{C}$ in type 2 diabetes. Journal of Lipid Research 2009;50(6):1216-22.
16. Sozmen B, Delen Y, Girgin FK, et al. Catalase and paraoxonase in hypertensive type 2 diabetes mellitus: correlation with glycemic control. Clinical Biochemistry 1999;32(6):423-7.

17. Barathi S, Angayarkanni N, Pasupathi A, et al. Homocysteinethiolactone and paraoxonase: novel markers of diabetic retinopathy. Diabetes Care 2010;33(9):2031-7.

18. Tuomilehto J. Epidemiology of macro vascular disease and hypertension in diabetes mellitus. In: Defronzo RA, Ferrannini E, Zimmet $\mathrm{P}$, et al. eds. International text book of diabetes mellitus. $3^{\text {rd }}$ edn. John Wileyand Sons Ltd., 2004;2:1345-54.

19. Tartan Z, Orhan G, Kasikcioqlu H, et al. The role paraoxonase enzyme in the extent and severity of the coronary artery disease in type 2 diabetic patients. Heart Vessels 2007;22(3):158-64.

20. Ayub A, Mackness MI, Arrol S, et al. Serum paraoxonase after myocardial infarction. Arterioscler Thromb Vasc Biol 1999;19(2):330-5.

21. Mackness MI, Arrol S, Abbott C, et al. Protection of LDL against oxidative modification by HDL associated paraoxonase. Atherosclerosis 1993;104(1-2):129-35.

22. Ozols J. Isolation and complete covalent structure of liver microsomal paraoxonase. Biochem J 1999;338(Pt 2):26572.

23. Mirdamadi HZ, Sztanek F, Derdak Z, et al. The human paraoxonase- 1 phenotype modifies the effect of statins on paraoxonase activity and lipid parameters. Br J Clin Pharmacol 2008;66(3):366-74.

24. Deakin S, Leviev I, Guernier S, et al. Simvastatin modulates expression of the PON1 gene and increases serum paraoxonase: a role for sterol regulatory element-binding protein-2. Arterioscler Thromb Vasc Biol 2003;23(11): 2083-9. 